\title{
Three Ownership Scenario Analyses of a Historic Site Management: Lessons Learned from a Historic Mill
}

\author{
Vishakha Maskey ${ }^{1}$, Alan R. Collins ${ }^{2} \&$ Cheryl Brown ${ }^{2}$ \\ ${ }^{1}$ Gary E. West College of Business, West Liberty University, West Liberty, USA \\ ${ }^{2}$ Agricultural and Resource Economics, West Virginia University, Morgantown, USA \\ Correspondence: Vishakha Maskey, Gary E. West College of Business, CSC \#123, West Liberty University, \\ West Liberty, WV 26074, USA. E-mail: vmaskey@westliberty.edu
}

Received: October 30, 2012 Accepted: November 8, 2012 Online Published: February 26, 2013

doi:10.5539/jms.v3n2p1 URL: http://dx.doi.org/10.5539/jms.v3n2p1

\begin{abstract}
Historic buildings have public attributes due to a diverse set of social values held by the general public, and maintaining them represents economic sustainability and a sense of place. Privately owned, profit driven historic places may generate these social values, but not capture them, thereby reducing the incentive to preserve (Navrud and Ready 2002). However, public ownership may account for the social benefits and enhance historic preservation. The objective of this paper is to examine how these social values impact benefit-cost analyses under three property right scenarios: private, non-profit, and public ownership. The historic site considered in this study is an agricultural grist mill (Reckart's Mill) in Preston County, West Virginia, USA. Analyses are evaluated under two cases: (1) a base case and (2) optimistic use and social value assumptions (upper case).

The results suggest that private ownership is not economically feasible under either case. Only public ownership is economically efficient under optimistic assumptions and a $4 \%$ discount rate. These results can be used as a basis for evaluating the appropriate property rights allocation of historic buildings, and could be expanded to other historic places under similar circumstances.
\end{abstract}

Keywords: benefit-cost analysis, sensitivity analysis, social values, non-market valuation

\section{Introduction}

Historic places have values for individuals that have been described as existence, option, altruistic, community identity, and recreational values (Heritage Counts, 2003). These values make historic building preservation important to current and future generations. Whether viewed as an exhaustible resource or part of a cultural heritage, historic buildings need preservation and restoration. Economic and social sustainability of a location is also enhanced by maintaining such resources, which in turn preserves sense of place and location integrity. Listing properties in the National Register of Historic Places (the National Register) is one of the most significant preservation efforts in the U.S.

There are three prevalent ownership scenarios for historic buildings: private, non-profit, and public. The Register does not consider property ownership in the listing process (Riebe, 2007). However, these different ownership scenarios convey different sets of rights to the general public.

In the case of privately owned historic buildings, property owners are given the primary use rights to the building, where profit maximization and private costs are primary considerations in preservation decisions because information regarding benefits accrued to the public are not accessible (Sterner, 2003). If available to the public, access rights are granted typically after paying an entrance fee. Often, there are external, social values generated from knowledge that historic buildings exist, and from viewing them from off-site. A private owner, however, may or may not be able to capture these external values from a historic building. Thus, owners may not consider these social values in preservation decisions.

In the second scenario, a historic building is privately owned by a non-profit organization. Such an organization typically has a stated mission (i.e. within organizational by-laws) to support or engage in activities of saving historic places, such as National Trust for Historic Preservation (2008). In this case, there is mixture of private and public rights as the non-profit organization acts in the public interest. 
In the case of publicly owned historic buildings, they are used collectively by society, tend to be less excludable, and can be enjoyed by everyone (Sterner, 2003). Being managed by a public agency, the general public has an expanded voice into the operation and preservation decisions made by public agencies. This voice can be construed as a greater degree of use rights over this historic building than the other two ownership scenarios.

Enhancing historic resource protection and meeting social goals of preserving historic values requires identification of priority places. Also, recognizing the most economically efficient property right scenario will promote sustainable preservation. Evaluating preservation efforts through tax revenues, entrance fees, or donations and charitable funds provides crucial information regarding resource allocation and ownership alternatives (Navrud and Ready 2002). In this same context, evaluating all benefits and costs of preserving a historic site and comparing property right scenario outcomes will assist in making informed public decisions about historic preservation.

The objective of this paper is to conduct benefit-cost analyses of historic building preservation under three property right scenarios: private ownership, private ownership with public support (non-profit), and public ownership. Results from these benefit-cost analyses will enable an evaluation of which property right scenario is best suited from an economic perspective to own and operate historic building resources. A case study of Reckart's Mill, a historic agricultural grist mill in West Virginia, is used in these analyses.

Maintenance and preservation of Reckart's Mill is evaluated by computing both Net Present Value (NPV) and Benefit-Cost $(\mathrm{B} / \mathrm{C})$ ratio. These benefit-cost analyses provide a comparison of private versus social perspectives to evaluate an economically efficient property right allocation for historic mill preservation. These analyses provide a framework to assess preservation for the case study and other similar historic sites.

\section{Background}

Historic buildings are unique resources that hold various use and non-use values including existence, option, altruistic, community identity, and recreational (Heritage Counts 2003). In addition, value of historic integrity and authenticity is also one aspect of these values (Maskey et. al., 2007). In order to protect these values, preservation and maintenance of these buildings is required. Neglecting these resources may lead to inefficiencies due to loss of social values. Accounting for the positive economic values of the society and correcting for the positive benefits generated by the historic buildings could possibly provide a more efficient process for the preservation of historic buildings.

Historic buildings are typically owned by private, non-profits, or government entities. All three ownership scenarios are present in existing historic agricultural mills (Table 1) (SPOOM, 2007). Most of these mills are operating, sell products and provide other tourism services. Regardless of ownership, historic buildings possess certain public good attributes due to intrinsic values held by the general public. These intrinsic values create positive benefits from the historic building for society.

Table 1. Few examples of different ownership for historic mills

\begin{tabular}{lll}
\hline \multicolumn{1}{c}{ Name of Historic Mill } & \multicolumn{1}{c}{ Ownership } & \multicolumn{1}{c}{ Location } \\
\hline Dellinger Gristmill & Jack Delinger (Private) & Bakersville, North Carolina \\
Bost Mill & Gene and Brenda Bost (Private) & Concord, North Carolina \\
Benson Mill & Group of Volunteers (Non-profit) & Stansbury Park, Utah \\
Murray's Mill & $\begin{array}{l}\text { Catawba County Historical Society } \\
\text { (Non-profit) }\end{array}$ & Catawba, North Carolina \\
& Anselma Preservation and & Anselma, Chester Spring, \\
The Mill at Anselma & Educational Trust (Non-profit) & California \\
& Babcock State Park (Public) & Clifftop, West Virginia \\
Glade Creek Grist Mill & West Virginia University (Public) & Weston, West Virginia \\
Jackson Mill & North Carolina State University & Raleigh, North Carolina \\
Yates Mill & (Public) & \\
& & \\
\hline
\end{tabular}

Source: SPOOM (2007)

In order to provide the right amount of cultural goods where resources are limited, comparing cost and benefits of providing one more historic good is crucial (Navrud and Ready, 2002). Since private owners of historic buildings focus on immediate costs and benefits of preservation, social values and intergenerational equity can 
be ignored since they tend to be unobservable. Accounting for these social values leads to improved efficiency in allocation of historic resources.

Opening a historic building to the public as a tourist attraction requires maintenance and upkeep, hiring of staff, and providing for security and insurance. In order to assess whether a historic building holds sufficient social valuessuch that preservation requires public intervention, estimation of the benefits provided by these social values is required. This paper provides an assessment of how use and non-use social values vary across property right scenarios and incorporates these social values into benefit-cost analyses for Reckart's Mill.

\subsection{Reckart's Mill Case Study}

Reckart's Mill was built in 1865 as a three-story post and beam gristmill, cider press, and wood planer. In 1980, it was listed in the National Register of Historic Places based on its significance for agriculture, social history, industry, architecture and engineering (National Register of Historic Places, 2006). It is located in a remote area of Preston County with poor quality roads and no nearby recreational opportunities or tourist destinations (such as stores and restaurants).

Reckart's Mill has always been privately owned. Reckart's Mill was purchased by the current owner in 1997. The mill was used as a tourist site, where flour was ground on the mill day. The mill was open from April to October on most Fridays and Saturdays and also accepted visitors by appointment any day. The mill was open to the public Friday and Saturday 10 a.m. to 4 p.m. and by appointment. The revenues generated from the mill came from its visitors. The mill owners also operated a store in the vicinity.

In 2002, there were 600 visitors, which decreased to 200 visitors on "Mill Day" in 2003 (Plum, 2003). A non-profit organization, Friends of Reckart's Mill, was created by the owners to restore the historic mill, but the group was not successful in raising enough funds to keep the mill open (Hardesty, 2004). A lack of visitors, financial difficulties and increasing insurance payments forced the owners to close the mill to the public in 2004 (Hardesty, 2004).

The mill closed and became non-functional in 2004 due to lack of funds to operate and pay for insurance (Hardesty, 2006). Since its closure, how many parts of the mill have been relocated to other mills is unknown. The closing and sale of parts of Reckart's Mill suggest that the private owner did not consider the social value, its historic authenticity. We argue that non-profit and public ownership would have considered this social value in the decision to preserve Reckart's Mill. Therefore, economic analyses of three different property right scenarios are conducted to evaluate if the outcome to preserve Reckart's Mill would have been different under an alternative ownership structure.

\section{Methods}

Benefit-cost analyses of historic preservation are conducted for each property right scenario: private ownership, private ownership with public support (non-profit), and public ownership. In order to conduct a benefit-cost analysis of historic preservation, four components must be determined: (1) monetary values for benefits and costs; (2) the flow of benefits and costs over time plus discounting to present values; (3) comparisons of discounted benefits versus discounted costs by computing NPV and B/C ratio; and (4) conduct sensitivity analyses. Each of these components is described below.

\subsection{Monetary Values}

Monetary value estimates are derived for four aspects of Reckart's Mill: social values for its preservation and being open to the public, tourism revenues, property value appreciation, and costs of ownership and operation. Benefits under private ownership include tourism revenues and property value appreciation while non-profit and public ownership include the sum of tourism revenue and social values. Costs are varied with ownership and the amount of visitor use. See Appendix A and B for a complete listing of information sources and assumptions utilized for tourism revenues and costs. Property value appreciation is described below in the "Cash Flows and Discounting" section. All monetary values are adjusted to 2006 values.

The social value of preserving and keeping Reckart's Mill open to the public is estimated using contingent valuation method (CVM).CVM is a non-market valuation technique that economists use to quantify the monetary value of goods and services which are not priced in markets. Maskey et al. (2007) describe in detail the CVM utilized for Reckart's Mill. Below is a summary of the methods and findings from this CVM study:

- A mail survey was conducted on a population of 23,304 households living in four counties within a 20 mile radius of the mill. A survey instrument was mailed to a sample of 1,000 households. The response rate was $26 \%$. 
- $\quad$ Respondents were asked to report their maximum, one time donation for keeping Reckart's Mill open and preserved at its original location

- A Tobit model was used to estimate the impact of respondent characteristics and attitudes on donation levels. Using this Tobit model, an average willingness to pay (WTP) of $\$ 8.45$ per household was computed across the sample.

- Using census data to reflect population demographics in the Tobit model, an average WTP of \$2.29 per household was extended to the entire population.

Variable cost information is based on the number of days the mill is open. It is assumed that the mill is open every weekend during the tourist season from April through October. This assumption was expanded to being open every day of the tourist season for the sensitivity analysis. Fixed costs of technical assistance and maintenance remain the same for all property right scenarios. Costs related to property taxes, labor, materials, utilities, insurance and mortgage varied across scenario and within the sensitivity analysis expressed in Appendix B (Maskey, 2007).

For the mortgage costs, it was assumed that the mill was purchased in 2005. The 1997 purchase price was appreciated by $1 \%$ annually (Preston county community information, 2006) and an interest rate of 5.9\% was used in computing annual payments for a 20 year mortgage (Federal Reserve Bank, 2007). This mortgage cost is applied only to the private owner and non-profit scenarios. In terms of public ownership, it is assumed that the mill is publicly owned via donation by a private owner so that no mortgage costs are included. This assumption is based on an example of Jackson Mill in West Virginia (West Virginia University, 2007).

\subsection{Cash Flows and Discounting}

The monetary values estimated for benefits and costs need to be organized over time into a cash flow analysis. These future cash flows are then discounted to present values (2006 in this analysis) (Lang and Marino 1993). These present values are used to conduct benefit-cost analyses for preserving Reckart's Mill. All three property right scenarios are evaluated in infinite time horizons using discounting formulas utilized in forestry economics (Klemperer, 1996). Given the shorter time horizon of private ownership, this scenario is evaluated with a 20 -year perpetual periodic series by assuming that each mill owner sells it after 20 years to retire. Table 2 presents the basic assumptions utilized for cash flow and discounting.

Table 2. Basic assumptions utilized for discounting and cash flows

\begin{tabular}{c}
\hline Assumptions \\
\hline$\circ \quad$ The annual costs and benefits are measured in "real" monetary values and \\
remain constant over time. \\
No replacement capital is required for the mill. \\
$\circ \quad$ Reckart's Mill property value appreciates at $1 \%$ annually (Preston County \\
Community Information 2007) from a projected purchase price of $\$ 59,457$ in \\
2005. This value is incorporated in the private owner scenario. Both public \\
and non-profit ownership scenarios do not include property value \\
appreciation. \\
A real discount rate of 4.66\% is assumed for the private owner and non-profit \\
scenarios. This rate is computed as the prime rate of $8.25 \%$ (Federal Reserve \\
Bank 2007) minus the historical inflation rate of 3.43\% (1913-2006). \\
Real discount rates of both $2 \%$ and $4 \%$ are used for the public ownership \\
scenario (Just, Hueth and Schmitz, 2004). \\
The mill's social value is assumed to be collected in year zero of the analysis. \\
This value is used in the non-profit and public ownership scenarios.
\end{tabular}

The main differences between scenario cash flows are how mortgage costs and property value appreciation are considered. Under private ownership, a re-occurring, 20-year mortgage is assumed given changing ownership. Each ownership change results in a realization of property value appreciation by the owner. In the non-profit scenario, the mortgage is paid off after the first 20 years, with zero mortgage costs thereafter. While a non-profit owner retains transfer rights, this owner chooses not to utilize these rights in deference to the public support received so that no property value appreciation is considered. The public ownership analysis does not include either the mortgage or appreciated property value, assuming that society values the mill in its preserved 
condition forever and would not want to sell it at any time in the future.

\subsection{Sensitivity Analyses}

Sensitivity analyses are employed to reflect fundamental uncertainties in assumptions about tourism revenues, social values, and discount rates utilized in the benefit-cost analyses. For tourism revenues, base and upper case are considered. In the upper case analyses, more visitors and higher average expenditure per visitor are assumed (Appendix A). Costs are varied with the number of visitors based on days that the mill is open plus variations in utility, labor, material, maintenance, and advertisement costs.

The social value of the mill depends on how well the survey sample represents the total population. The base case is the computed average WTP adjusting for demographic differences between the survey sample and the general population. The upper case assumes that the survey sample accurately reflects the general population with no adjustments. Under non-profit ownership, this social value is $\$ 105,403$ for the base case and $\$ 212,425$ for the upper case. Since the WTP estimates from Maskey et al. (2007) applied only to non-profit ownership, the social value under the public ownership scenario used WTP values $(\$ 11.61$ per household for the sample and $\$ 3.46$ per household for the entire population) that are adjusted based on respondents' preferences for public ownership. In this scenario, the base case social value is $\$ 130,077$ and the upper case is $\$ 288,109$. These economic values are assumed to occur in year zero of the analysis given that they reflect the existence value of the mill being open and available to the public.

The choice of a discount rate can have a large impact on the outcome of benefit-cost analysis (Field 2005). For the public property right scenario, $2 \%$ and $4 \%$ discount rates are used. These rates reflect a range of social discount rates as suggested by Just, Hueth and Schmitz (2004).

\section{Results}

Table 3 presents the sums of present value benefits and costs. Non-profit ownership has the lowest total present value cost due to a relatively high discount rate used for the base case. Similarly, public ownership has the highest total present value cost due to much lower discount rates used for future costs. Public ownership also has the largest total present value benefits at both the base and upper cases. Under public ownership, social value contributes $48 \%$ and $51 \%$ of the total benefit in the base and upper cases, respectively.

Table 3. Present value benefits and costs for each scenario under base and upper cases

\begin{tabular}{|c|c|c|c|c|}
\hline \multirow[t]{2}{*}{ Ownership } & \multirow[t]{2}{*}{ Private } & \multirow[t]{2}{*}{ Non-profit } & \multicolumn{2}{|c|}{ Public } \\
\hline & & & $\begin{array}{c}\text { (2\% Discount } \\
\text { Rate) }\end{array}$ & $\begin{array}{c}\text { (4\% Discount } \\
\text { Rate) }\end{array}$ \\
\hline $\begin{array}{l}\text { Total cost } \\
\text { Base }\end{array}$ & $\$ 365,103$ & $\$ 355,230$ & $\$ 617,700$ & $\$ 308,850$ \\
\hline Upper & $\$ 526,172$ & $\$ 478,225$ & $\$ 904,250$ & $\$ 452,125$ \\
\hline $\begin{array}{l}\text { Total benefit } \\
\text { Base }\end{array}$ & $\$ 228,135$ & $\$ 228,236$ & $\$ 416,277$ & $\$ 273,177$ \\
\hline Upper & $\$ 280,030$ & $\$ 448,910$ & $\$ 840,109$ & $\$ 564,109$ \\
\hline $\begin{array}{l}\text { Base Social } \\
\text { value }\end{array}$ & & $\$ 105,403$ & $\$ 130,077$ & $\$ 130,077$ \\
\hline $\begin{array}{l}\text { Upper social } \\
\text { value }\end{array}$ & & $\$ 212,425$ & $\$ 288,109$ & $\$ 288,109$ \\
\hline
\end{tabular}

$\mathrm{NPV}$ and $\mathrm{B} / \mathrm{C}$ ratios are computed in order to evaluate the economic consequences from Reckart's Mill preservation (Table 4). Under the base case, all NPV are less than zero and B/C ratios are less than 1.0. These results mean that under the most likely benefit and cost assumptions, preserving and keeping open Reckart's Mill would result in more costs than benefits regardless of who owned the mill - private, non-profit or public. Depending upon the discount rate, public ownership either results in the highest loss (at 2\%) or the least loss (at $4 \%)$. 
For the upper case, the private owner perspective still results in more costs than benefits, with the NPV being even larger at $-\$ 246,142$. Even if monetary estimates of social values are added to the private owner scenario, NPV remains negative $(-\$ 123,697)$ and $\mathrm{B} / \mathrm{C}$ ratio is less than one $(0.53)$. When Reckart's mill is operated by a non-profit organization, the mill has a negative NPV under both base and optimist revenue and social value assumptions. Under public ownership, only the higher discount rate under upper case assumptions shows a positive NPV $(\$ 111,984)$ and a B/C ratio greater than $1.0(1.25)$. Table 4 results mean that preserving and keeping open Reckart's Mill can be economically efficient, but only under public ownership and if optimistic visitation and social value computations are assumed to occur.

Table 4. NPV and B/C ratio for each scenario under base and upper cases

\begin{tabular}{llclc}
\hline Variable & \multicolumn{2}{c}{ Base } & \multicolumn{2}{c}{ Upper } \\
\hline Ownership & NPV & B/C ratio & NPV & B/C ratio \\
Private & $(\$ 136,196)$ & 0.62 & $(\$ 246,142)$ & 0.53 \\
Non-profit & $(\$ 126,994)$ & 0.64 & $(\$ 29,316)$ & 0.94 \\
Public & $(\$ 201,423)$ & 0.67 & $(\$ 64,141)$ & 0.93 \\
{$[2 \%$ discount rate $]$} & & & & \\
Public & $(\$ 35,673)$ & 0.88 & $\$ 111,984$ & 1.25 \\
{$[4 \%$ discount rate $]$} & & & \\
\hline Values in parentheses are negative. & & & \\
\hline
\end{tabular}

\section{Conclusion and Policy Implications}

These economic analyses confirm that Reckart's Mill is not economically viable for a private owner to operate and preserve, even when the social value is considered. From a purely economic standpoint, operating Reckart's Mill under private ownership is not efficient. This result confirms the reality of Reckart's Mill being closed to the public. Also under the most likely benefit and cost projections, non-profit and public ownership also would result in economic inefficiencies. The isolation and lack of additional amenities around Reckart's Mill make its preservation and keeping it open to the public an economic challenge regard less of ownership. However, property right scenarios of public ownership do generate economically efficient outcomes, but only at optimistic levels of visitation and social values.

The differing results of private versus non-profit or public ownership are reflected in the mills that are currently open. There are numerous agricultural grist mills in the U.S. that are either owned by public agencies or by non-profit organizations. In some cases, entrance is free, but social value has been captured for publicly owned mills in the form of an involuntary contribution made by society through taxation. Moreover, preservation should be based on a long term maintenance plan with additional attributes or amenities for attracting tourists, which is the case for most of the currently functioning historic mills.

The public ownership scenario demonstrates once again that the discount rate utilized in the analysis plays an important role in determining economic feasibility. An unusual feature of this analysis is that the higher discount rate of $4 \%$ generated larger NPV and $\mathrm{B} / \mathrm{C}$ ratio than a $2 \%$ rate. In many benefit-cost analyses, negative net returns accrue in the early years of the analysis, while positive net returns are generated in later periods. However, for preservation of Reckart's Mill, the social value in year zero generates the largest net return, which is followed in subsequent years by negative cash flows to keep the mill open and available to the public. Thus, a higher discount rate generates a larger NPV than lower discount rates, contrary most other benefit-cost analyses of public goods. This sequence of cash flows implies that taxpayers would have to subsidize the operation and maintenance of Reckart's Mill over time to keep it open.

The local community's social value for preserving the authenticity and keeping Reckart's Mill open plays an important role in making the public ownership scenario economically efficient. This value contributes $32 \%$ to the total benefits for base case and $35 \%$ for the upper case. If the public's value had been incorporated into the preservation decision process and through involvement of a non-profit group, then the public would have had a property right to the mill and the mill may not have been closed to the public. Again, public ownership and 
degree of irreversible loss of the mill to society is contingent upon the availability of funds to allocate in preserving the mill.

From a broader social perspective, there may be acceptable substitutes for Reckart'sMill. To the local community, however, there may not be any substitutes for their heritage and culture. Thus, either local government intervention or involvement of a non-profit organization would be required to preserve this mill. Assistance of a non-profit organizationalso is vital if the social value expressed by the general public is to be converted into revenue to preserve the mill.

Future research is needed to figure out new ways to collect preservation values from society other than tax dollars. Moreover, determination of the opportunity cost of developing historic buildings into new buildings for commercial purposes would generate more informed decisions. In addition to this benefit-cost analysis using WTP, a community's Willingness to Accept (WTA) estimates could be used in the benefit-cost framework to shed further light on the values placed on historic preservation and integrity. WTA estimates may be useful to measure the amount needed to compensate the loss of heritage and community identity of the Reckart's Mill community.

\section{References}

Amick, J. (2006). Office Assistant, Babcock State Park. Telephone Communication on September, 19.

Babcock State Park. (2006). Retrieved November 7, 2006 from http://www.stateparks.com/babcock_fayette.html (Accessed).

Bartrug, D. (2006). Business Account Specialist, Allegheny Power, West Virginia. Telephone communication August 3.

Bost, G., \& Bost, B. (2007). History of Bost Grist Mill. Retrieved from http://www.bostgristmill.com/html/calendar_of_events.html

Federal Reserve Bank. (2007). Selected interest rate, Federal Reserve Statistical Release, July 30. Retrieved December 15, 2006 from http://www.federalreserve.gov/releases/h15/Current/

Federal Reserve Board. (2006). Historical Chart of Prime rate effective since June 29. Retrieved February 2007 from http://www.moneycafe.com/library/prime.htm

Field, B. C. (2005). Natural Resource Economics: An Introduction. Long Grove, IL: Waveland Press.

Hardesty, G. (2006). Reckart's Mill owner, Preston County, West Virginia. Telephone Communication.

Hardesty, T. (2004). Reckart's Mill owner, Preston County, West Virginia. Personal Communication.

Hardman, D. (2006). WVU Jackson Mill's Program Coordinator. Telephone Communication.

Heritage Counts. (2003). The Economic Value of the Historic Environment. The Value of the Built Heritage: A Report prepared by National Economic Research Associates. Retrieved May 1, 2006 from http://www.english-heritage.org.uk/heritagecounts/newpdfs/DATA2.pdf

Inflation data.com. (2007). Decade Inflation Chart. Retrieved May, 2007 from http://inflationdata.com/Inflation/images/charts/Articles/Decade_inflation_chart.htm

Just, D., Darrell, L., \& Schmitz, A. (2004). The Welfare Economics of Public Policy: A Practical Approach to Project and Policy Evaluation. Edward Elgar, Cheltenham, UK, Northampton, MA, USA.

Klemperer, W. D. (1996). Forest Resource Economics and Finance. New York: McGraw-Hill.

Lang, H. J., \& Marino, D. N. (1993). The Selection Process for Capital Projects. A Wiley-Interscience Publication, John Wiley \& Sons, Inc, NY.

Locals.com. (2006). Source for Web advertising. Retrieved May 12, 2007 from http://register.local.com/default.aspx?keyword=advertising + price+web\&cid=2106\&gid=Local_Promote_W eb_Advertising

Maskey, V. (2007). Economic Analyses Explaining Historic Preservation: The Impact of Social and Economic Values, Dissertation, West Virginia University. Retrieved from https://eidr.wvu.edu/etd/documentdata.eTD?documentid=5406

Maskey, V., Brown, C., Collins, A. R., \& Nassar, H. F. (2007). What is Historic Integrity Worth to the General Public? Evidence from a Proposed Relocation of a West Virginia Agricultural Mill. Agricultural and Resource Economics Review, 36(1), 39-52. 
National Park Service. (2006). History and Culture. Retrieved April 28, 2006 from http://www.cr.nps.gov/buildings.htm

National Park Service. (2007). Technical Preservation Service, U.S. Department of Interior. 2007. Historic Preservation and Tax Incentives. Retrieved June 15, 2007 from http://www.cr.nps.gov/hps/tps/tax/index.htm

National Trust for Historic Preservation. (2008). Resources for Homeowners. Retrieved from http://www.preservationnation.org

Navrud, S., \& Ready, R. C. (2002). Valuing Cultural Heritage: Applying Environmental Valuation Techniques to Historic Buildings, Monuments and Artifacts. Cheltenham, U.K.: Edward Elgar Publishing.

Plum, K. (2003). Historic wheel may be moved to Bruceton Mills. The Dominion Post, November 17.

Preston County Community Information. (2007). Real Estate in Preston County West Virginia. Retrieved June 24, 2007 from http://local.reply.com/real-estate/WV/preston-county.html\#homes

Riebe, E. (2007). National Register Coordinator, State Historic Preservation Office, West Virginia. Personal communication on June 23.

SPOOM (The Society for the Preservation of Old Mills). (2007). Organizational Members with Mill Open to the Public. Retrieved May 20, 2007 from http://spoom.org/locator/States-HTML/USAMapOpenMills.htm

Spot Runner, Inc. (2005). Retrieved May 30, 2007 from http://spotrunner.reachlocal.net/ads/ads.aspx?industryid=AN3T

Sterner, T. (2002). Policy Instruments for Environmental and Natural Resource Management. RFF Press, Washington DC, USA.

Tietenberg, T. (2002). Environmental and Natural Resource Economics (6th ed.). Addison Wesley Publication Company.

Titchenell, M. (2007). Preston County Tax Office. Telephone Communication on June 5.

Torries, T. F. (1998). Evaluating Mineral Projects: Applications and Misconceptions. Society of Mining, Metallurgy, and Exploration, Inc.

Tyler, N. (2000). Historic Preservation: An Introduction to Its History, Principles and Practice. W.W. Norton and Company, New York, London.

U.S. Census Bureau. (2000). State and County Quick Facts. Retrieved June 3, 2006 from http://quickfacts.census.gov/qfd/

U.S. Department of Labor. (2007). Minimum Wage. Retrieved May 11, 2007 from http://www.dol.gov/dol/topic/wages/minimumwage.htm

VistaPrint.com. (2007). Web Source for printing flyers. Retrieved May 12, 2007 from $\mathrm{http} / / / \mathrm{www} . v i s t a p r i n t . c o m / \mathrm{vp} / \mathrm{ns} / \mathrm{splash} /$ splash_datasheets.aspx?

West Virginia University. (2007). WVU Jacksons Mill's Historic Area. WVU Jackson Mill's State 4-H Camp, Extension Service. Retrieved September 19, 2007 from Available online at http://www.wvu.edu/ EXTEN/depts/jmill/jmh_area.htm

Workman, J. (2007). Babcock Gift Shop Manager, Babcock State Park, WV. Telephone communication on September 21. 


\begin{tabular}{|c|c|c|c|c|}
\hline Variable & $\begin{array}{l}\text { Assumptions and } \\
\text { Data sources }\end{array}$ & & $\begin{array}{l}\text { Annual } \\
\text { Totals }\end{array}$ & \\
\hline & (Base) & (Upper) & (Base) & (Upper) \\
\hline Annual Visitation & 600 visitors $^{\mathrm{a}}$ (Plum 2003) & $\begin{array}{l}1000 \text { visitors }^{\mathrm{a}} \text { (Projected } \\
\text { from mail survey data) }\end{array}$ & & \\
\hline Entrance Fees & $\begin{array}{l}\$ 7 \text { for adults and } \$ 5 \text { for } \\
\text { senior citizens (Bost Grist } \\
\text { Mill in Concord, NC) }\end{array}$ & $\begin{array}{l}\$ 7 \text { for adults and } \$ 5 \text { for } \\
\text { senior citizens(Bost Grist } \\
\text { Mill in Concord, NC) }\end{array}$ & $\$ 3,624$ & $\$ 6,040$ \\
\hline $\begin{array}{l}\text { Revenue from } \\
\text { Expenditures }\end{array}$ & $\begin{array}{l}\$ 3.5 \text { per visitor based on a } \\
50 \% \text { markup from an } \\
\text { average of } \$ 7 \text { worth of } \\
\text { expenditure per visitor } \\
\text { (Amick 2006) }\end{array}$ & $\begin{array}{l}\$ 5 \text { per visitor based on a } \\
50 \% \text { markup from an } \\
\text { average of } \$ 10 \text { worth of } \\
\text { expenditure per visitor } \\
\text { (Amick 2006) }\end{array}$ & $\$ 2,100$ & $\$ 5,000$ \\
\hline
\end{tabular}

a $48 \%$ of visitors are assumed to be senior citizens based on mail survey responses from likely visitors.

Appendix B: Cost data

\begin{tabular}{|c|c|c|c|c|}
\hline \multirow{2}{*}{ Variable } & \multicolumn{2}{|l|}{ Assumptions and Data sources } & \multicolumn{2}{|c|}{ Annual Totals } \\
\hline & (Base) & (Upper) & (Base) & (Upper) \\
\hline \multicolumn{5}{|c|}{ Variable Costs } \\
\hline Materials & $\begin{array}{l}\text { Depending on the number of visitor lower } \\
\text { number of visitor (Babcock State Park, } \\
\text { Amick 2006) }\end{array}$ & Higher number of visitor & $\$ 300$ & $\$ 2,000$ \\
\hline Labor & $\begin{array}{l}\text { No labor cost } \$ 5.15 / \mathrm{hr} \text { (U.S. Department of } \\
\text { Labor, 2007) }\end{array}$ & $\begin{array}{l}\text { Open every day for sixty days in } \\
\text { tourist season }\end{array}$ & $\$ 0$ & $\$ 1,854$ \\
\hline Utilities & $\begin{array}{l}\text { Open } 60 \text { days during season } \$ 60 \text { per day } \\
\text { (Dave Bartrug, Allegheny Power Company, } \\
\text { 2006) }\end{array}$ & $\begin{array}{l}\text { Open } 90 \text { weekdays and } 60 \\
\text { weekends. Half day open on } \\
\text { weekdays. Therefore, total of } \\
105 \text { days }\end{array}$ & $\$ 3,600$ & $\$ 6,300$ \\
\hline Mortgage & $\begin{array}{l}\text { Assuming mortgage increase at } 1 \% \text { rate } \\
\text { annually, the annual payment rate was } \\
\text { estimated for every } 20 \text { year period. (Preston } \\
\text { County, Community Information, 2007). }\end{array}$ & Same rate for both cases. & $\$ 4,200$ & $\$ 4,200$ \\
\hline Insurance & $\begin{array}{l}\text { Insurance cost in } 2002 \\
\text { (Hardesty, 2004) }\end{array}$ & Insurance cost in 2003 & $\$ 1,400$ & $\$ 2,200$ \\
\hline Advertising & $\begin{array}{l}\text { Cost of brochure, and web advertisement } \\
\text { (VistaPrint, } 2007 \text { and Locals.com 2007)) }\end{array}$ & $\begin{array}{l}\text { Additional television } \\
\text { advertisement (SpotRunner.com } \\
\text { 2007) }\end{array}$ & $\$ 572$ & $\$ 1,104$ \\
\hline \multicolumn{5}{|l|}{ Fixed Costs } \\
\hline Maintenance & $\begin{array}{l}\text { Fixed for both case. (Babcock State Park } \\
\text { Maintenance Cost, Amick, 2006) }\end{array}$ & & $\$ 2,000$ & $\$ 2,000$ \\
\hline Property & Average tax for period of $2001-2006$ & & $\$ 176$ & $\$ 176$ \\
\hline Tax & $\begin{array}{l}\text { Preston County Court House (Titchenell, } \\
\text { 2007). }\end{array}$ & & & \\
\hline Technical & $\begin{array}{l}\text { Fixed for both case. (Babcock State Park } \\
\text { Maintenance Cost, Amick, 2006) }\end{array}$ & & $\$ 4,306$ & $\$ 4,306$ \\
\hline
\end{tabular}

